\title{
Impaired Beta Adrenergic Receptor Binding and Function in Cystic Fibrosis Neutrophils
}

\author{
Stanley P. Galant, lydia Norton, John Herbst, and Carolyn Wood, \\ Department of Pediatrics, University of Utah, Salt Lake City, Utah 84321
}

A в S T R A C T Cystic fibrosis (CF), a genetic disease characterized by abnormalities of exocrine gland and mucociliary function, has recently been shown to be associated with abnormal adrenergic and cholinergic physiologic responses in addition to decreased beta adrenergic-induced cyclic AMP generation in human leukocytes. In this study we have attempted to elucidate the nature of this hyporesponsiveness by assessing beta adrenergic receptor number and affinity $\left(K_{\mathrm{D}}\right)$ in the intact neutrophil using the antagonist ligand $\left[{ }^{3} \mathrm{H}\right]$ dihydroalprenolol and cyclic AMP responses to isoproterenol in addition to histamine, and prostaglandin $\mathrm{E}_{1}$ in $\mathrm{CF}$ subjects, $\mathrm{CF}$ obligate heterozygotes (CFH), and normal control subjects. CF patients had significantly less $(P<0.025)$ cyclic AMP stimulation above basals levels with isoproterenol $(0.1 \mu \mathrm{M}$ to $0.1 \mathrm{mM}$ ), compared with control values, but no consistent differences between groups were noted with histamine or $\mathrm{PGE}_{1}$. CF neutrophils had significantly fewer $(P<0.005)$ beta adrenergic receptors per neutrophil $(398.0 \pm 54.2$ vs. $819.4 \pm 67.2)$ compared with control neutrophils, but the $K_{\mathrm{D}}(0.740 \pm 0.11$ vs. 0.630 $\pm 0.05 \mathrm{nM})$ did not differ significantly $(P>0.05)$. There was no correlation between clinical severity and either cyclic AMP generation or dihydroalprenolol binding $(r=0.27$ and 0.24 , respectively, $P>0.05)$. The CFH group had $\sim 50 \%$ of the cyclic AMP stimulation compared with controls, but the number $(909.8 \pm 89.3)$ and $K_{\mathrm{D}}(0.710 \pm 0.09 \mathrm{nM})$ of their beta adrenergic receptors were indistinguishable from control subjects. These findings suggest "down regulation" of the beta receptor in the CF patient. The cause of this remains unknown. Although the etiology of the decreased cyclic AMP responses in CFH was not due to decreased beta adrenergic receptors as assessed by antagonist ligand binding, further studies in the CFH

\footnotetext{
Address reprint requests to Dr. Galant, Memorial Hospital Medical Center of Long Beach, Calif.

Received for publication 12 August 1980 and in revised form 23 March 1981.
}

group to include agonist binding, receptor-adenylate cyclase coupling, intrinsic adenylate cyclase activity, and catecholamine metabolism may help determine the basic cause of beta adrenergic hyporesponsiveness in both CFH and CF.

\section{INTRODUCTION}

Cystic fibrosis $(\mathrm{CF})^{1}$ is a genetic disease characterized by abnormal exocrine secretion and mucoiliary activity $(1,2)$. The pathogenesis of the disease remains unknown at present, but because of the importance of the autonomic nervous system (ANS) in regulating exocrine gland secretion, assessment of adrenergic and cholinergic function has become a major topic of investigation. For example, chronic administration of pharmacologic agents with ANS activity to laboratory animals has been shown to produce exocrine gland function and morphology that closely resembles those seen in CF $(3,4)$. Physiologic assessment of the ANS in CF has revealed decreased beta adrenergic, and heightened alpha and cholinergic function (5-8). The molecular basis for an ANS abnormality in CF has been best studied for the beta adrenergic system since this pathway, involving the generation of the second messenger cyclic AMP, has been most clearly elucidated (9). The majority of studies utilizing human tissue have used the skin fibroblast, because this cell produces ciliostatic factor (10) and was thought to be free of drugs and other in vivo effects such as the severity of CF. Unfortunately, data using this model have conflicted with several studies showing enhanced beta adrenergic responses $(11,12)$, whereas others report no difference in isoproterenol-induced cyclic AMP generation between CF and control populations (13). These contradictory observations probably reflect the large number of variables inherent in tissue culture systems.

\footnotetext{
${ }^{1}$ Abbreviations used in this paper: ANS, autonomous nervous system; CF, cystic fibrosis; $\mathbf{C F H}$, cystic fibrosis heterozygote(s); DHA, dihydroalprenolol.
} 
The human neutrophil offers a number of advantages in this regard. This cell type can be highly purified $(>95 \%)$ in relatively large numbers $\left(2 \times 10^{8} / 60 \mathrm{ml}\right)$ without the necessity to establish a cell line in culture. Regulation of neutrophil lysosomal enzyme secretion is controlled by the same neurotransmitters as are found in exocrine tissues. Secretion is inhibited by mediators that increase intracellular cyclic AMP (isoproterenol, histamine, and prostaglandin $\left.\mathrm{E}_{1},\left[\mathrm{PGE}_{1}\right]\right)$ and is enhanced by agents that increase cyclic guanosine $5^{\prime}$ monophosphate (GMP) (carbachol) in addition to being calcium dependent as well $(14,15)$. Another similarity between these two tissues is the importance of microtubules and microfilaments in macromolecular secretion (16). Thus, defective ANS regulation of exocrine tissue could be manifest in the CF neutrophil. Using human leukocytes, Davis et al. (17) reported decreased cyclic AMP generation with isoproterenol, but not $\mathrm{PGE}_{1}$ stimulation in $\mathrm{CF}$ and in some CF heterozygote (CFH) subjects. The nature of this selective defective response was not elucidated.

We have previously characterized the beta adrenergic receptor in neutrophil sonicates (18). More recently, Dulis and Wilson (19), as well as ourselves (20), have successfully established the presence of these receptors in the intact cell, using the beta adrenergic antagonist ligand $\left[{ }^{3} \mathrm{H}\right]$ dihydroalprenolol (DHA). DHA binding in our system is rapid, reversible, and stereoselective, and demonstrates beta- 2 rank order potency. We have applied this technique to measure neutrophil beta adrenergic receptor binding in addition to cyclic AMP generation in $\mathrm{CF}$ and obligate $\mathrm{CFH}$ subjects to determine whether previous observations could have been based on defective beta adrenergic receptors.

\section{METHODS}

Subjects. For this study the CF population consisted of 23 subjects, 14 males and 9 females, with a mean age of 18.5 $\pm 1.3 \mathrm{yr}( \pm \mathrm{SEM})$. Two patients were receiving theophylline, one patient received occasional beta adrenergic aerosol, and one received terbutaline tablets. Beta adrenergic agonists, methylxanthines, and aspirin were prohibited within $24 \mathrm{~h}$ of the study period. 53\% of the patients were receiving antibiotics during the study period. Clinical assessment was made using the Shwachman-Kulczycki system (21), whereby a score of 100 indicates no disease and a score of 45 indicates severe disease. $79 \%$ of the subjects had pancreatic insufficiency, and $26 \%$ had atopic disease with histories consistent with allergic rhinitis and bronchial asthma. There were $10 \mathrm{CFH}$ parents of the CF patients: 5 males and 5 females, with a mean age of $38.1 \pm 2.9 \mathrm{yr}( \pm \mathrm{SEM}$ ), and 36 healthy control subjects without personal or family histories of asthma or cystic fibrosis. The latter group consisted of 28 females and 8 males, with a mean age of 25.5 $\pm 1.0 \mathrm{yr}( \pm \mathrm{SEM})$. The control and CFH subjects were not receiving medication at the time of study.

Cell preparation. Neutrophils were prepared and assayed for cyclic AMP by the method of Davis et al. (17). Whole blood was collected in nonheparinized glass tubes containing a dextran (mol wt 170,000, Sigma Chemical Co., St. Louis, Mo.)-heparin (sodium, preservative-free, Sigma Chemical Co.) mixture in a proportion 5:1), and allowed to settle for 25-30 $\mathrm{min}$ at room temperature. The leukocyte-rich fraction was then underlayered with Ficoll-Hypaque and spun at $400 \mathrm{~g}$ for $30 \mathrm{~min}$ at $20^{\circ} \mathrm{C}(22)$, and the resulting pellet washed three times with physiologic saline. The neutrophils in the pellet constituted $>95 \%$ of the nucleated cells in this fraction. The percentage of band forms (immature neutrophils) was determined by counting 100 nucleated cells stained with Wright stain. CF patients had $11.5 \pm 0.87 \%$ band forms, whereas control subjects had $3.6 \pm 0.5 \%$ band forms.

Cyclic AMP assay. For the cyclic AMP assay $5 \times 10^{6}$ neutrophils per tube were preincubated for $5 \mathrm{~min}$ at room temperature in incubation buffer $(50 \mathrm{mM}$ Tris, $\mathrm{pH} 7.5$, and $8 \mathrm{mM}$ theophylline in physiologic saline) and then exposed to media alone or to hormones (isoproterenol, histamine, and $\left.P G E_{1}\right)$ at $37^{\circ} \mathrm{C}$ in a total volume of $100 \mu \mathrm{l}$ for $5 \mathrm{~min}$. Accumulation of cyclic AMP was terminated by boiling for $5 \mathrm{~min}$ and freezing for $\geq 30 \mathrm{~min}$. The samples were thawed and assayed for cyclic AMP by the saturation method of Brown et al. (23). This method permitted quantitative recovery of exogenous $\left[{ }^{3} \mathrm{H}\right]$ cyclic AMP. The results are expressed as picomoles per $10^{6}$ cells. The change in neutrophil cyclic AMP after incubation with agonists is expressed as the percentage increase over basal cyclic AMP levels.

DHA binding assay. The binding assay used the same incubation condition as for cyclic AMP. $\left[{ }^{3} \mathrm{H}\right] \mathrm{DHA}(0.1-10 \mathrm{nM})$ was incubated with $5 \times 10^{6}$ neutrophils per tube containing an incubation volume of $180 \mu \mathrm{l} 1 \mathrm{mM}$ ascorbic acid, 0.1 $\mathrm{mM}$ phentolamine, and $0.3 \mathrm{mM}$ catechol (which are thought to block nonreceptor binding sites) $(24,25)$ for $15 \mathrm{~min}$ at $37^{\circ} \mathrm{C}$, and stopped with $5 \mathrm{ml}$ of Tris, $50 \mathrm{mM} \mathrm{HCl}$, and $10 \mathrm{mM}$ $\mathrm{MgCl}_{2}$ for $30 \mathrm{~s}$. The mixture was then rapidly filtered through a Gelman A-E glass fiber filter presoaked with stop buffer containing $0.1 \mathrm{mM}$ dl propranolol (Gelman Sciences, Inc., Ann Arbor, Mich.). The filters were rapidly washed with $25 \mathrm{ml}$ incubation buffer and counted in a liquid scintillation system. Specific binding represents the total number of DHA counts minus DHA binding in the presence of $0.3 \mu \mathrm{M} \mathrm{dl}$ propranolol, and was $50-80 \%$ of the total amount bound at all DHA concentrations. We have recently demonstrated the importance of phentolamine $(0.1 \mathrm{mM})$ in reducing nonspecific DHA binding (19). At this concentration phentolamine reduces nonspecific binding (from 69 to $33 \%$ ) without affecting binding to specific receptor sites. All samples were run in duplicate and differed from each other by $\leq 15 \%$. Specific binding was linear with the cell number used for these experiments.

Calculations. (a) Receptor number was calculated from the expression: Receptors/cell =

$$
\begin{aligned}
\frac{\text { mol of DHA bound }}{\text { mg protein }} \times \frac{1 \mathrm{mg} \text { protein }}{1.8 \times 10^{7} \text { cells }} & \\
& \times \frac{6.02 \times 10^{23} \text { molecules }}{\mathrm{mol}} .
\end{aligned}
$$

(b) Statistical analysis utilized nonpaired Student's $\boldsymbol{t}$ test and correlation coefficient. (c) Percentage of cyclic AMP stimulation = stimulated cyclic AMP minus basal cyclic AMP/basal cyclic AMP $\times 100 \%$.

Materials. Most reagents were obtained from sources previously listed (18). Components for the cyclic AMP assay were purchased from Amersham Corp., Arlington Heights, Ill. 


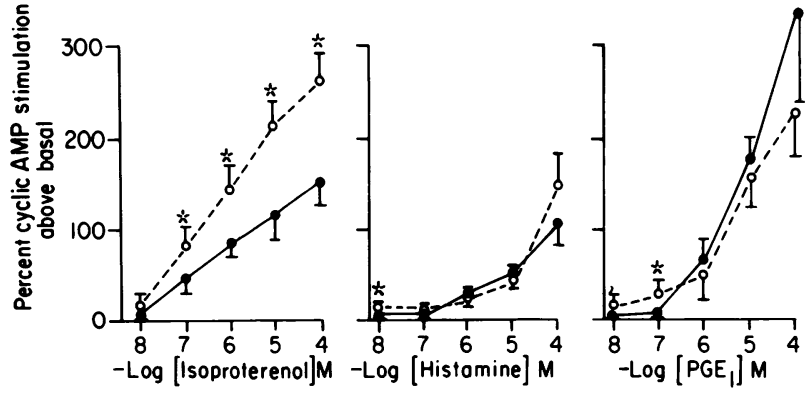

Figure 1 Comparison of CF (O) and control subjects' $(O)$ agonist stimulation of neutrophil cyclic AMP. Each agonist was incubated with $5 \times 10^{6}$ cells for $5 \mathrm{~min}$ at $37^{\circ} \mathrm{C}$ after a 5 -min preincubation in incubation buffer consisting of $50 \mathrm{mM}$ Tris (pH 7.5) in physiologic saline and $8 \mathrm{mM}$ theophylline (17). Shown is the percentage of cyclic AMP stimulation above basal values (mean $\pm S E M$ ) for each agonist ( $10 \mathrm{nM}$ to $0.1 \mathrm{mM})$. The only consistently significant differences $\left({ }^{*}\right)$ between the two study populations occurred with isoproterenol stimulation $(P<0.025)$. For isoproterenol there were 37 experiments in the control, 33 in CF group; for histamine and $P G E_{1}$ the number of experiments was 7 and 6 for control and CF groups, respectively.

\section{RESULTS}

Cyclic AMP responses. Fig. 1 illustrates a comparison of isoproterenol, histamine, and $\mathrm{PGE}_{1}$-induced cyclic AMP generation of CF and control subjects' neutrophils, expressed as percentage of stimulation over basal levels. CF patients had significantly less $(P<0.025)$ beta adrenergic induction of adenylate cyclase than controls at $0.1 \mu \mathrm{M}$ to $0.1 \mathrm{mM}$ isoproterenol concentrations, as shown by nonpaired Student's $t$ test analysis. There were no consistent differences in cyclic AMP generation induced by either histamine or $\mathrm{PGE}_{1}$, although $10 \mathrm{nM}$ histamine and $0.1 \mu \mathrm{M} \mathrm{PGE}_{1}$ were more potent in control subjects $(P<0.025)$. In Table I the data are expressed as absolute values (pmol/10 $10^{6}$ cells). CFH are also analyzed. The absolute quantity of cyclic AMP in CF neutrophils was significantly lower for basal $(P<0.025)$ and for all isoproterenol concentrations used compared with control levels $(P<0.005)$, whereas $\mathrm{CFH}$ were significantly lower than normal controls at isoproterenol concentrations of $1 \mu \mathrm{M}$ to $0.1 \mathrm{mM}(P<0.05)$. CFH cyclic AMP levels were significantly greater $(P<0.05)$ than those found in CF subjects for basal and all beta adrenergic hormone responses. Histamine and $\mathrm{PGE}_{1}$ were again not consistently different in $\mathrm{CF}$ and normal controls.

DHA binding. A DHA concentration curve comparing control subjects with CF and CFH subjects shows that there is no difference between control and CFH populations, but both groups have significantly more $(P<0.01)$ DHA binding at all ligand concentrations than the CF group (Fig. 2A). A Scatchard plot analysis of the mean data for each group shows that DHA bound to a single class of high affinity sites on the neutrophil membrane (Fig. 2B). The mean \pm SEM for $\mathrm{B}_{\max }$ and $K_{\mathrm{D}}$ calculated from Scatchard analysis of all subjects is shown in Table II. From these data the total number of receptors/neutrophil was determined. These data reveal that both the control with $819.4 \pm 67.2$ (mean $\pm \mathrm{SEM}$ ) receptors/neutrophil and the $\mathrm{CFH}$ group

TABLE I

Absolute Cyclic AMP Levels in CF, CFH, and Control Subjects after Agonist Stimulation

\begin{tabular}{|c|c|c|c|c|c|c|}
\hline \multirow[b]{2}{*}{ Subject group } & \multicolumn{6}{|c|}{ Agonist } \\
\hline & Basal & 8 & 7 & 6 & 5 & 4 \\
\hline & \multicolumn{6}{|c|}{$(-\log M)\left(p m o l / 10^{6}\right.$ cells $)$} \\
\hline & \multicolumn{6}{|c|}{ Isoproterenol } \\
\hline Control $(n=37)$ & $1.30 \pm 0.17$ & $1.30 \pm 0.17$ & $1.86 \pm 0.23$ & $2.35 \pm 0.22$ & $2.70 \pm 0.24$ & $3.24 \pm 0.25$ \\
\hline CF $(n=33)$ & $0.87 \pm 0.18^{*}$ & $0.55 \pm 0.09^{*}$ & $0.88 \pm 0.12^{*}$ & $1.12 \pm 0.13^{*}$ & $1.26 \pm 0.15^{*}$ & $1.38 \pm 0.15^{*}$ \\
\hline \multirow[t]{2}{*}{ CFH $(n=8)$} & $1.44 \pm 0.08$ & $1.45 \pm 0.07$ & $1.75 \pm 0.10$ & $1.89 \pm 0.09 \ddagger$ & $2.04 \pm 0.11 \ddagger$ & $2.14 \pm 0.08$ \\
\hline & \multicolumn{6}{|c|}{ Histamine } \\
\hline Control $(n=7)$ & $1.62 \pm 0.35$ & $1.52 \pm 0.30$ & $1.70 \pm 0.37$ & $1.95 \pm 0.45$ & $2.25 \pm 0.45$ & $3.44 \pm 0.48$ \\
\hline \multirow[t]{2}{*}{$\mathrm{CF}(n=6)$} & $0.99 \pm 0.22$ & $0.76 \pm 0.27$ & $0.94 \pm 0.26$ & $1.19 \pm 0.26$ & $1.39 \pm 0.26$ & $1.79 \pm 0.31^{*}$ \\
\hline & \multicolumn{6}{|c|}{$\mathrm{PGE}_{1}$} \\
\hline Control $(n=7)$ & $1.62 \pm 0.35$ & $1.59 \pm 0.35$ & $1.89 \pm 0.41$ & $2.18 \pm 0.43$ & $3.51 \pm 0.51$ & $4.38 \pm 0.84$ \\
\hline $\mathrm{CF}(n=6)$ & $0.99 \pm 0.22$ & $0.88 \pm 0.20$ & $0.96 \pm 0.23$ & $1.42 \pm 0.24$ & $2.23 \pm 0.32 *$ & $3.09 \pm 0.50$ \\
\hline
\end{tabular}

* $P<0.025$, comparing control and CF subjects.

$\ddagger P<0.05$, comparing control and CFH subjects. 

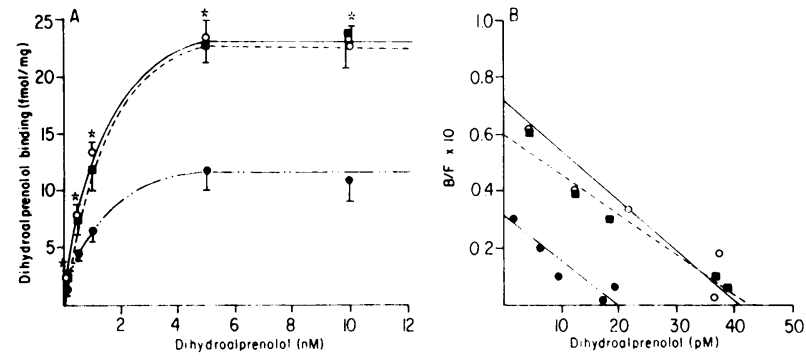

Figure 2 (A) $\left[{ }^{3} \mathrm{H}\right]$ DHA concentration curve for $\mathrm{CF}$ patients

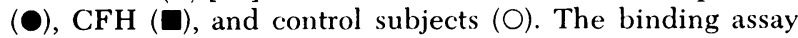
utilized the same incubation conditions as for cyclic AMP. DHA $(0.1-10 \mathrm{nM})$ was incubated with $5 \times 10^{6}$ cells $/ 180 \mu \mathrm{l}$ incubation volume containing $1 \mathrm{mM}$ ascorbic acid, $0.1 \mathrm{mM}$ phentolamine, and $0.3 \mathrm{mM}$ catechol for $15 \mathrm{~min}$ at $37^{\circ} \mathrm{C}$. Details of the procedure are given in Methods. Specific binding ( $\mathrm{fmol} /$ $\mathrm{mg}$ ) represents the total number of DHA counts minus DHA binding in the presence of $0.3 \mu \mathrm{M}$ dl propranolol. $2 \times 10^{7}$ neutrophils is equivalent to $1 \mathrm{mg}$ protein (18). Shown is the mean \pm SEM DHA binding in $11 \mathrm{CF}$ experiments, compared with $10 \mathrm{CFH}$ and 21 control experiments. ${ }^{*}$, indicates significant differences $(P<0.01)$ between $C F$ patients and both control or CFH subjects at each DHA concentration. Only specific DHA binding is shown. (B) Scatchard plot analysis of the mean data from (A). This shows that DHA binds to a single class of high affinity receptor. The total number of receptors is markedly decreased in CF (13.04 fmol/mg), whereas the dissociation constant $\left(K_{\mathrm{D}}\right)$ is similar: $0.66 \mathrm{nM}$ for $\mathrm{CF}$ compared with 0.58 and $0.43 \mathrm{nM}$ for $\mathrm{CFH}$ and controls, respectively.

with $909.8 \pm 89.3$ receptors/neutrophil had significantly more $(P<0.005)$ receptors than the CF patients with $398.0 \pm 54.2$ receptors/neutrophil. The $K_{\mathrm{D}}$ values of $0.630 \pm 0.05 \mathrm{nM}, 0.740 \pm 0.11 \mathrm{nM}$, and $0.710 \pm 0.9 \mathrm{nM}$ for

TABLE II

Beta Adrenergic Receptor Binding in CF

\begin{tabular}{cccc}
\hline \multicolumn{1}{c}{ CF patient } & $\mathrm{B}_{\max }{ }^{*}$ & $K_{\mathrm{D}}$ t & Clinical score $\$$ \\
\hline & fmol/mig protein & & \\
1 & 11.46 & 1.31 & 35 \\
2 & 11.20 & 1.20 & 35 \\
3 & 7.81 & 0.37 & 35 \\
4 & 4.35 & 0.92 & 73 \\
5 & 14.29 & 0.99 & 65 \\
6 & 14.29 & 0.93 & 35 \\
7 & 10.56 & 0.35 & 95 \\
8 & 17.20 & 0.44 & 65 \\
9 & 18.32 & 0.53 & 90 \\
10 & 15.63 & 0.31 & 95 \\
Mean \pm SEM & $12.51 \pm 1.23$ & $0.74 \pm 0.11$ & \\
CFH $(n=10)$ & $27.2 \pm 2.69$ & $0.71 \pm 0.09$ & \\
Controls $(n=21)$ & $24.8 \pm 1.60$ & $0.63 \pm 0.05$ & \\
$P$ (vs. controls) & $<0.005$ & $>0.05$ & \\
$P$ (vs. CFH) & $<0.005$ & $>0.05$ & \\
\hline
\end{tabular}

* Maximum number of binding sites.

\$ Dissociation constant.

\$ Shwachman-Kulczycki system (20).

" $\mathrm{CFH}$ are the C.F heterozygote parents. control, $\mathrm{CF}$, and $\mathrm{CFH}$ groups, respectively, did not differ significantly $(P>0.05)$.

The severity of CF (Shwachman-Kulczycki score) did not correlate with either the maximum percentage of isoproterenol $(0.1 \mathrm{mM})$-induced cyclic AMP stimulation or DHA binding at saturation ( $5 \mathrm{nM}$ DHA concentration). There also appeared to be no correlation between cyclic AMP responsiveness or beta adrenergic receptor binding and the presence of pancreatic insufficiency, atopy, or the administration of antibiotics or prior bronchodilator therapy (data not shown). The percentage of neutrophil band forms did not correlate with either the percentage of cyclic AMP stimulation $(r=0.35, P>0.05)$, or the absolute quantity of cyclic AMP generated $(r=-0.16, P>0.05)$ after maximal isoproterenol $(0.1 \mathrm{mM})$ stimulation (Table III). Furthermore, although the CF patients were somewhat younger $(18.5 \pm 1.3 \mathrm{yr})$ than control subjects $(25.5 \pm 1.0 \mathrm{yr})$, this is not a likely explanation for the differences noted, because there was no significant correlation between age and DHA binding or cyclic AMP stimulation in our study population.

\section{DISCUSSION}

We have confirmed the observation in CF neutrophils reported by Davis et al. (17) that suggests defective

TABLE III

Relationship of Immature Neutrophil Forms and Cyclic AMP Responses in CF Subjects

\begin{tabular}{|c|c|c|c|}
\hline \multirow[b]{2}{*}{ CF subjects } & \multicolumn{3}{|c|}{ Cyclic AMP } \\
\hline & Stimulation & Cells & $\begin{array}{l}\text { Neutrophil } \\
\text { band forms }\end{array}$ \\
\hline & $\%$ & $p m o l / 10^{6}$ & $\%$ \\
\hline 1 & 78 & 0.91 & 11 \\
\hline 2 & 166 & 0.77 & 10 \\
\hline 3 & 100 & 2.20 & 10 \\
\hline 4 & 24 & 0.31 & 10 \\
\hline 5 & 20 & 0.60 & 9 \\
\hline 6 & 64 & 0.54 & 12 \\
\hline 7 & 178 & 0.75 & 17 \\
\hline 8 & 111 & 3.80 & 18 \\
\hline 9 & 79 & 1.00 & 15 \\
\hline 10 & 93 & 1.16 & 7 \\
\hline 11 & 630 & 0.73 & 15 \\
\hline 12 & 265 & 0.73 & 15 \\
\hline 13 & 58 & 2.26 & 9 \\
\hline 14 & 68 & 3.30 & 2 \\
\hline 15 & 396 & 1.34 & 13 \\
\hline 16 & 56 & 2.00 & 14 \\
\hline 17 & 100 & 2.00 & 8 \\
\hline 18 & 500 & 0.60 & 12 \\
\hline
\end{tabular}

Correlation coefficient $(r)$ for neutrophil cyclic AMP stimulation (second column) and for absolute cyclic AMP levels (third column) with $0.1 \mathrm{mM}$ isoproterenol was $0.35(P>0.05)$ and $-0.16(P>0.05)$, respectively. 
cyclic AMP generation that is quite specific for the beta adrenergic pathway since neither histamine nor $\mathrm{PGE}_{1}$-induced adenylate cyclase activation appears abnormal, and since the intrinsic activity of adenylate cyclase itself is normal (26). In contrast to those investigators who report normal receptor number (27), however, we find a marked (50\%) decrease in the number of beta adrenergic receptors in CF neutrophils without a change in receptor affinity, as assessed by DHA binding. The reason for this discrepancy is not clear. Davis and Hill (27), who measured DHA binding in mononuclear membrane preparations, reported $\sim 250 \mathrm{fmol} / \mathrm{mg}$ membrane protein, which is considerably greater DHA binding than is reported by either our previous study with neutrophil sonicates (20) or that of Davies and Lefkowitz (28). Details of their methodology are not provided (27). Furthermore, since our study deals with DHA binding in the intact neutrophil, a direct comparison of our data with those of Davis and Hill (27) may not be appropriate. We must add that although a significant reduction in DHA binding was not found in $\mathrm{CFH}$, it is conceivable that a small $(\leq 25 \%)$ reduction in receptor sites might be missed because of lack of this degree of sensitivity of our assay system.

These findings, suggestive of down regulation of the beta adrenergic receptor associated with the desensitization phenomenon, are generally produced by chronic beta adrenergic stimulation (29). We have previously demonstrated down regulation in neutrophil sonicates with administration of the beta-2 agonist terbutaline (30), and others have reported this phenomenon in patients with pheochromocytoma (31), and after administration of antidepressants (32), which block reuptake of catecholamines. The CF patients, in general, were not receiving drugs known to cause this effect, but they could have increased endogenous catecholamine secretion as a result of chronic stress. This is not entirely consistent with the lack of correlation between severity of disease and beta adrenergic responses, or with the presence of decreased cyclic AMP generation in the CFH not under stress. Furthermore, we were unable to demonstrate an effect of pancreatic function, atopy, or neutrophil maturity on beta adrenergic function in the $\mathrm{CF}$ population. These findings are suggestive of a primary genetic defect in the beta adrenergic system itself. The cause of the decreased cyclic AMP response in CFH is not clear, since it is not associated with reduction in receptor numbers, at least as measured by antagonist ligand binding. Perhaps the desensitization model may prove useful in explaining this finding. Decreased cyclic AMP responses following chronic exposure to isoproterenol may be due to several mechanisms dependent on the cell source, duration of exposure, and concentration of agonist $(33,34)$. Thus, decreased responsiveness without a change in receptor number measured by antagonist ligands, such as DHA, could be due to decreased agonist binding (34) or an uncoupling of receptor to the enzyme adenylate cyclase (33). A more profound effect, usually with high agonist concentration or long duration of exposure in some cell types, is a decrease in receptor number (measured by antagonist binding) consistent with diminished adenylate cyclase responsiveness (33). Desensitization is frequently agonist specific (35), so that beta adrenergic down regulation is not usually associated with decreased responses to histamine or $\mathrm{PGE}_{1}$.

The beta adrenergic defect in CF could be a continuum with the CFH population having normal antagonist binding but abnormal agonist binding or abnormal receptor-enzyme coupling, so that the result is decreased cyclic AMP generation, whereas the $\mathrm{CF}$ patient has a more severe defect consisting of decreased antagonist binding and adenylate cyclase activation. If a desensitization phenomenon is the basic mechanism behind our observation, we are still without an explanation for this effect. One might consider an intrinsic cellular defect with an increased propensity to desensitize; circulating catecholamine levels that are chronically evaluated, owing to increased synthesis or decreased uptake; or inhibitory substances produced by the CF cell (11). Other than for the last named, there is no evidence for these hypotheses in the literature, and in fact one investigation reports decreased norepinephrine levels in $\mathrm{CF}$, although it presents no data (13). Physiologic studies in CFH (5-8), however, clearly demonstrate ANS imbalance, and this could be associated with disordered catecholamine metabolism. Study of CFH may hold the key to the primary defect in CF.

Finally, the relationship of the beta adrenergic defect to the disease process deserves comment. The fact that several investigators $(5,13)$, as well as ourselves, have found evidence of ANS abnormalities in the asymptomatic CFH subject makes such phenomena less likely to be important in the pathogenesis of CF. Nevertheless, the CFH population must be further studied to define clearly such beta adrenergic differences between them and the CF group as receptor binding, coupling, activation of adenylate cylase, and catecholamine metabolism. This might not only provide a useful marker of the heterozygote state, but may also shed light on the relationship between beta adrenergic function and pathogenesis of the disease state.

\section{ACKNOWIEDGMENTS}

This study was supported by a grant from the Cystic Fibrosis Foundation.

Dr. Galant is a recipient of an Allergic Diseases Academic Award (A100304) from the National Institute of Allergy and Infectious Diseases. 


\section{REFERENCES}

1. di Sant' Agnese, P. A., and P. B. Davis. 1976. Research in cystic fibrosis. N. Engl. J. Med. 29: 597-602.

2. Wanner, A. 1977. Clinical aspects of mucociliary transport. Am. Rev. Respir. Dis. 116: 73-125.

3. Martinez, J. R., P. C. Adshead, D. O. Quissel, and G. J. Barbers. 1975. The clinically reserpinized rat as a possible model for cystic fibrosis. I. Submaxillary gland morphology and ultra structure. Pediatr. Res. 9: 463-469.

4. Mangos, J. A., N. R. McSherry, P. J. Benke, and A. Spock. 1969. Studies on the pathogenesis of cystic fibrosis: the isoproterenol-treated rat as an experimental model. In Proceedings of the Fifth International Cystic Fibrosis Conference, Churchill College, 22-26, September 1969. D. Lawson, editor. Cystic Fibrosis Research Trust, Cambridge, England. 25-34.

5. Davis, P. B., J. R. Shelhamer, and M. Kaliner. 1980. Abnormal adrenergic and cholinergic sensitivity in cystic fibrosis. N. Engl. J. Med. 302: 1453-1456.

6. Rubin, L. S., G. J. Barbers, and W. S. Chernick. 1966. Pupillary dysfunction as a concomitant of cystic fibrosis. Pediatrics. 38: 865-873.

7. Chernick, W. S., G. J. Barbers, and F. M. Parkins. 1961. Studies on submaxillary saliva in cystic fibrosis.J. Pediatr. 59: 890-898.

8. Mitchell, I., M. Corey, R. Woenne, I. R. B. Krastins, and H. Levison. 1978. Bronchial hyperactivity in cystic fibrosis and asthma. J. Pediatr. 93: 744-748.

9. Sutherland, E. W., and R. W. Rall. 1960. The relationship of adenosine $3^{\prime}, 5^{\prime}$ phosphate and phosphorylase to the actions of catecholamines and other hormones. Pharmacol. Rev. 12: 265-299.

10. Danes, B. S., and A. G. Bearn. 1972. Oyster ciliary inhibition by cystic fibrosis culture medica. J. Exp. Med. 136: $1313-1317$.

11. Roscher, A. A., A. J. Schmid, B. Hadorn, and N. Wisemann. 1980. Enhanced adenosine $3^{\prime}: 5^{\prime}$-monophosphate response to beta adrenergic stimulation in cystic fibrosis fibroblasts after removal of conditioned medium. Pediatr. Res. 14: 261-265.

12. Buchwald, M. 1976. Abnormal levels of $3^{\prime}: 5^{\prime}$-cyclic AMP in isoproterenol stimulated fibroblasts from patients with cystic fibrosis. Proc. Natl. Acad. Sci. U. S. A. 73: 28992903.

13. Davis, P. B., S. C. Hill, and M. M. Ulane. 1980. Hormone stimulated cyclic AMP production by skin fibroblasts cultured from healthy persons and patients with cystic fibrosis. Pediatr. Res. 14: 863-868.

14. Ignarro, L. J., and W. J. George. 1974. Hormonal control of lysosomal enzyme release from human neutrophils: elevation of cyclic nucleotide levels by autonomic neurohormones. Proc. Natl. Acad. Sci. U. S. A. 71: 2027-2031

15. Smith, R. J., and L. J. Ignarro. 1975. Bioregulation of lysosomal enzyme secretion from human neutrophils: roles of guanosine $3^{\prime}: 5^{\prime}$ monophosphate and calcium in stimulus-secretion coupling. Proc. Natl. Acad. Sci. U. S. A. 72: 108-112.

16. Zurier, R. B., G. Weissman, and S. Hoffstein. 1974. Mechanisms of lysosomal enzyme release from human leukocytes. II. Effects of cAMP and cGMP, autonomic agonists, and agents which affect microtubule function. J. Clin. Invest. 53: 297-309.

17. Davis, P. B., M. Braunstein, and C. Jay. 1978. Decreased adenosine $3^{\prime}: 5^{\prime}$-monophosphate response to isopro- terenol in cystic fibrosis leukocytes. Pediatr. Res. 12: 703-707.

18. Galant, S. P., and S. J. Allred. 1980. Demonstration of beta- 2 adrenergic receptors of high coupling efficiency in human neutrophil sonicates. J. Lab. Clin. Med. 96: 15-23.

19. Dulis, B. H., and I. B. Wilson. 1980. The $\beta$ receptor of live human polymorphonuclear leukocytes. J. Biol. Chem. 255: 1043-1048.

20. Galant, S. P., and S. J. Allred. 1981. Binding and functional characteristics of beta adrenergic receptors in the intact neutrophil. J. Lab. Clin. Med. In press.

21. Shwachman, H., and L. L. Kulczycki. 1958. Long term study of 105 patients with cystic fibrosis. Am. J. Dis. Child. 96: $6-15$.

22. Böyum, A. 1968. Isolation of mononuclear cells and granulocytes from blood. II. Isolation of mononuclear cells by 1 centrifugation and of granulocytes by combining centrifugation and sedimentation of lg. Scand. J. Clin. Invest. 21: 77-89.

23. Brown, B. C., J. D. M. Albano, R. P. Ekins, and A. H. Sgherzi. 1971. A simple and sensitive saturation assay for the measurement of adenosine $3^{\prime}: 5^{\prime}$ cyclic monophosphate. Biochem. J. 121: 561-562.

24. Lefkowitz, R. J., and L. T. Williams. 1977. Catecholamine binding to the beta adrenergic receptor. Proc. Natl. Acad. Sci. U. S. A. 74: 514-519.

25. Sporn, J., and P. B. Molinoff. 1976. Adrenergic receptors in rat brain. J. Cyclic Nucleotide Res. 2: 149-161.

26. Davis, P. B., and S. C. Laundon. 1980. Adenylate cyclase in leukocytes from patients with cystic fibrosis. J. Lab. Clin. Med. 96: 75-84.

27. Davis, P. B., and S. C. Hill. 1979. Adenyl cyclase and beta receptors in mononuclear cells from patients with cystic fibrosis. Am. Rev. Respir. Dis. 119: 302. (Abstr.)

28. Davies, A. O., and R. J. Lefkowitz. 1980. Corticosteroidinduced differential regulation of $\mathrm{B}$ adrenergic receptors in circulatory human polymorphonuclear leukocytes and mononuclear leukocytes. J. Clin. Endocrin. Metab. 51: 599-605.

29. Mickey, J., R. Tate, and R. J. Lefkowitz. 1975. Subsensitivity of adenylate cyclase and decreased $\mathrm{B}$ adrenergic receptor binding after chronic exposure to (-) isoproterenol in vitro. J. Biol. Chem. 250: 4727-5729.

30. Galant, S. P., L. Duriseti, S. Underwood, and P. A. Insel. 1978. Decreased beta adrenergic receptors on polymorphonuclear leukocytes after adrenergic therapy. N. Engl. J. Med. 299: 933-936.

31. Greenacre, J. D., and M. E. Conolly. 1978. Desensitization of the B adrenoceptor of lymphocytes from normal subjects and patients with phaeochromocytoma: studies in vivo. Br. J. Clin. Pharmacol. 5: 191-197.

32. Banerjee, S. P., L. S. Kung, S. J. Rizzi, and S. K. Chandra. 1977. Development of B adrenergic receptor subsensitivity by antidepressants. Nature (Lond.). 268: 455-456.

33. Su, Y. F., K. Harden, and J. P. Perkins. 1979. Isoproterenol-induced desensitization of adenylate cyclase in human astrocytoma cells: relation of loss of hormonal responsiveness and decrement in $\mathrm{B}$ adrenergic receptors. J. Biol. Chem. 254: 38-41.

34. Wessels, M. R., D. Mullikin, and R. J. Lefowitz. 1978. Differences between agonist and antagonist binding following beta adrenergic receptor desensitization. J. Biol. Chem. 253: 3371-3373.

35. Hoffman, B. B., and R. J. Lefkowitz. 1980. Radioligand binding: studies of adrenergic receptors: new insights into molecular and physiological regulation. Am. Rev. Pharmacol. Toxicol. 20: 581-608. 